\title{
ENHANCING REGULATION OF NUTRACEUTICAL PRODUCTS IN MALAYSIA: LESSONS FROM JAPAN*
}

\author{
Suzi Fadhilah Ismail ${ }^{* *}$ \\ Mahyuddin Daud ${ }^{* * *}$ \\ Ida Madieha Abdul Ghani Azmi ${ }^{* * * *}$ \\ Juriah Abd Jali1 ${ }^{* * * * *}$
}

\begin{abstract}
The phenomenal commercial success of many nutraceutical products, dietary and health supplements indicate increasing levels of consumer acceptance to the usage of health supplements in Malaysia. As much as these products are consumed for health purposes, lack of effective control by drug authority leaves much to be desired. Legal issues such as marketing approval, product liability, safety, advertising, trade description (nutrition labelling \& health claims) would undoubtedly emerge as direct implications from widespread sales and consumption of such products. Consumers' health and safety are at risk where nutraceuticals can easily penetrate into the market without any need of undergoing clinical studies, as opposed to pharmaceuticals. This article was written based on research that has identified several causal factors to the above-mentioned issues. First, nutraceuticals are loosely classified as in between food and drugs. Due to the loose classification scheme, manufacturers tend to opt that their products be classified as food to escape strict clinical evaluations. This leads to the issue of misleading health claims made on its labels and advertisements. The article examines the regulation of nutraceuticals in Malaysia and identifies
\end{abstract}

* This paper is funded by the Fundamental Research Grant Scheme (FRGS), granted by the Ministry of Higher Education Malaysia under the Project ID: (FRGS16-005-0504).

** Assistant Professor, Ahmad Ibrahim Kulliyyah of Laws, International Islamic University Malaysia. Email: suzi@iium.edu.my.

*** Assistant Professor, Ahmad Ibrahim Kulliyyah of Laws, International Islamic University Malaysia. Email: mahyuddin@iium.edu.my.

**** Professor, Ahmad Ibrahim Kulliyyah of Laws, International Islamic University Malaysia. Email: imadieha@iium.edu.my.

${ }^{* * * * *}$ Associate Professor, Ahmad Ibrahim Kulliyyah of Laws, International Islamic University Malaysia. Email: juriah@iium.edu.my. 
significant issues therein. Comparative analysis with Japanese nutraceutical regulations was made to learn how Japanese classifies its nutraceuticals under specific categories known as 'Food for Specified Health Uses (FOSHU)'. Products bearing the FOSHU logo went through strict clinical tests and are allowed to make health claims on their labels - and were proven effective and safe for consumption as claimed. The article made several recommendations for the establishment of a legal framework to regulate nutraceutical products in Malaysia.

Keywords: nutraceutical, drugs, regulation, safety, FOSHU.

\title{
MENINGKATKAN PENGAWAL SELIAAN PRODUK NUTRASEUTIKAL DI MALAYSIA: PELAJARAN DARI JEPUN
}

\begin{abstract}
ABSTRAK
Kejayaan komersial produk nutraseutikal, pemakanan dan makanan kesihatan menunjukkan peningkatan tahap penerimaan pengguna terhadap penggunaan suplemen kesihatan di Malaysia. Walaupun produk-produk ini digunakan untuk tujuan kesihatan, kekurangan kawalan yang berkesan oleh pihak berkuasa banyak menimbulkan persoalan. Isu-isu undang-undang seperti kelulusan pemasaran, liabiliti produk, keselamatan, pengiklanan, keterangan perdagangan (label pemakanan \& tuntutan kesihatan) pasti akan muncul sebagai implikasi langsung dari penjualan dan pengambilan produk yang meluas. Kesihatan dan keselamatan pengguna berisiko di mana nutraseutikal dapat menembusi pasaran dengan mudah tanpa perlu melalui kajian klinikal, berbanding farmaseutikal. Article ini ditulis berdasarkan kajian yang telah dikenal pasti beberapa faktor penyebab kepada isu-isu yang dinyatakan di atas. Pertama, pengklasifikasian nutraseutikal sebagai di antara kategori makanan dan dadah yang longgar. Oleh kerana skim pengkelasan yang longgar, pengeluar cenderung memilih bahawa produk mereka dikelaskan sebagai makanan untuk melepaskan penilaian klinikal yang ketat. Ini membawa kepada isu mengenai tuntutan kesihatan yang mengelirukan yang dibuat pada label dan iklannya. Makalah ini mengkaji peraturan nutraseutikal di Malaysia dan mengenal pasti isu-isu penting di dalamnya. Analisis perbandingan dengan peraturan nutraseutikal Jepun dibuat untuk mengetahui bagaimana Jepun mengklasifikasikan nutraseutikal terutamanya di bawah kategori tertentu yang dikenali sebagai 'Food for Specified Health Uses (FOSHU)'. Produk yang mengandungi logo FOSHU melalui ujian klinikal yang
\end{abstract}


ketat dan dibenarkan untuk membuat tuntutan kesihatan pada label mereka - dan terbukti berkesan dan selamat untuk digunakan seperti yang didakwa. Artikel ini membuat beberapa saranan untuk penubuhan rangka kerja undang-undang untuk mengawal selia produk nutraseutikal di Malaysia.

Kata Kunci: nutraseutikal, dadah, peraturan, keselamatan, FOSHU.

\section{INTRODUCTION}

There has been a growing trend amongst Malaysian consumers to opt for nutraceutical products. This due to the increasing awareness of health issues that are closely linked with dietary intake and eating lifestyle. The growing demand for nutraceutical products is mainly attributed to its proclaimed benefit to maintain health and wellbeing. The rapid rise of healthcare cost is also another driving factor which prompts consumers to opt for the concept of preserving good health from food, in alternative to prescribed drugs and modern medicines. It is found that the escalating popularity of nutraceutical products are very obvious specifically for the population from the middle- and the high-income group as they are becoming more health-conscious. These parts of the population have resorted to food supplements, nutraceutical, and herbal products to maintain a healthy lifestyle. Undoubtedly, nutraceutical products contribute to a substantial portion of the Malaysian health care sector affecting the public at large.

Globally, the natural healthcare industry is growing rapidly, which opens up huge opportunities and vast potential for those nutraceutical industry players. In terms of global statistics, the rapid growth of the nutraceutical market in the United Statesy, for instance, is estimated to increase steadily at a Compound Annual Growth Rate of $5.5 \%$. The figure, as reported by the United States Transparency Market Research, was projected to reach US $\$ 102.6$ billion by 2024 , from US $\$ 64.8$ billion in 2016. In Malaysia, based on an analysis by Technavio's research analyst, the health supplement market is projected to grow at a Compound Annual Growth Rate (CAGR) of 7\% annually.

1 Transparency Market Research, "Market Research Report," Transparency Market Research, 2015 , https://www.transparencymarketresearch.com/us-nutraceuticalsmarket.html. 
The local market is mainly dominated by the vitamins and dietary supplements, with an impressive market share of approximately $49 \%$ in 2014. The trend was estimated to grow until the end of 2019. The analyst has attributed such a figure to the factor of raising awareness among the consumers on the importance of food supplements.

\section{DEFINITIONS OF' 'NUTRACEUTICAL}

Nutraceutical, is a relatively new terminology which is apparently a combination of 'nutrition' and 'pharmaceutical'. It essentially denotes "food or food product that reportedly provides health and medical benefits, including the prevention and treatment of disease". ${ }^{2}$ Interestingly, the concept of nutraceutical emerges due to the evolution and link between 'nutrition' and 'health'. This so-called nutraceutical revolution is said to be the driving force for the food industry to become a research-oriented sector, which is similar if not equivalent to the pharmaceutical industry. ${ }^{3}$ Despite various definitions of the term nutraceutical, the gist lies on an important element of food or related ingredients to provide its consumers with the benefit of increased health and wellbeing, more than what is offered by conventional food products with general nutrition. ${ }^{4}$ There are some other words that are related to the concept of nutraceutical. 'Functional food' and 'dietary supplements' for instance, are sometimes used interchangeably to denote similar meaning with nutraceutical in various jurisdictions, but some authors argue that those terminologies carry slightly different meanings. Since different jurisdictions have their own terminologies to regulate nutraceutical or equivalent products, it is interesting to note that Japan has been using the term 'functional foods' since the mid1980s to regulate "processed foods containing ingredients that worked in the health and the physiological effects on the human body like the

2 K. P. Sampath Kumar Debjit Bhowmik, Harish Gopinath, B. Pragati Kumar, S. Duraivel, "Nutraceutical-A Bright Scope and Opportunity of Indian Health Market," The Pharma Innovation 1, no. 11 (2013): 29-41.

3 M. Prasad Palthur, S. Sajala Palthur, and Suresh Kumar Chitta, "Nutraceuticals: A Conceptual Definition," International Journal of Pharmacy and Pharmaceutical Sciences 2, no. 3 (2010): 19-27.

4 A Fatimah, "Functional Foods from the Dietetic Perspective," Jurnal Kesihatan Masyarakat Isu Khas (2002): 8-13, http://journalarticle.ukm.my/4410/. 
nervous system, immune system and the body's defence outside the function of nutrients". 5

In the European Union, there is no specific regulation dealing with nutraceutical but the EU Directive 2002/46/EC 3 referred to the term 'food supplements' and 'novel foods' instead. A "food supplement" is defined in Directive 2002/46/EC 3 as:

"Foodstuffs the purpose of which is to supplement the normal diet and that are concentrated sources of nutrients or other substances with a nutritional or physiological effect, alone or in combination, marketed in dose form, namely forms such as capsules, pastilles, tablets, pills and other similar forms, sachets of powder, ampoules of liquids, drop dispensing bottles, and other similar forms of liquids and powders designed to be taken in measured small unit quantities".

"Novel foods" are defined in Regulation (EC) No 258/976 as foods and food ingredients that have not been used for human consumption to a significant degree within the Community before 15 May 1997 and which fall under various categories.

In another jurisdiction such as Canada, there is no specific legislation governing nutraceutical as it falls either in the category of food or drugs. A product may be considered as drugs if it satisfies the definition of drugs. A 'drug' is defined in the Food and Drugs Act 1985 as:

\footnotetext{
"Any substance or mixture of substances manufactured, sold or represented for use in (a) the diagnosis, treatment, mitigation or prevention of a disease, disorder, abnormal physical state, or the symptoms thereof, in man or animal, (b) restoring, correcting or modifying organic functions in man or animal or, (c) disinfection in premises in which food is manufactured, prepared or kept".
}

If a product meets the said criteria, it will be regulated as a subset of drugs under the Natural Health Products Regulations. On the other hand, Food and Drugs Act 1985 defines "food" as "any article

5 Toshio Shimizu, "Health Claims on Functional Foods: The Japanese Regulations and an International Comparison," Nutrition Research Reviews, 2003, https://doi.org/10.1079/NRR200363. 
manufactured, sold or represented for use as food or drink by man, chewing gum, and any ingredient that may be mixed with food for any purpose whatever." Although there exists no specific legislation on nutraceutical, an attempt to define the term has been made by the Nutritional Sciences Bureau of the Food Directorate of Health Canada. According to the Bureau, nutraceutical is "a product isolated or purified from foods that is generally sold in medicinal forms not usually associated with food. A nutraceutical is demonstrated to have a physiological benefit or provide protection against chronic disease". 6

In the United States, nutraceuticals are known as dietary supplements. ${ }^{7}$ It is a product that contains nutrients derived from food products that are concentrated in liquid, capsule, tablets, soft gels, gel caps, or powder form. Section 3 of the Dietary Supplement Health and Education Act (DSHEA) 1994 provides dietary supplement a product that contains dietary ingredients such as vitamins, minerals, herbs or other botanicals and amino acids that are intended to supplement the diet. Such a product needs no approval from the United States Food and Drug Administration (FDA) before it can be marketed. As this product claims to provide health benefits, the Commission on Dietary Supplement Labels, established under Section 12(c) of DSHEA 1994, holds the duty to evaluate how best to provide truthful, scientifically valid, and not misleading information to consumers. This is to help such consumers to make informed and appropriate health care choices for themselves and their families.

Meanwhile, in India, the Food Safety and Standard Act 2006 had created a special third category for 'Food for Dietary Uses/Functional Foods/Nutraceutical/Health Supplements' in addition to the first two categories namely conventional food and drugs. This is to allow those products to have specific regulatory requirements. ${ }^{8}$ Since the term nutraceutical is broad and lacks uniform definitions, it is a need for the term to be defined with precision for regulatory purposes. A clear definition is needed as in certain jurisdictions, it is unclear whether such a product should remain as either food or drugs.

6 Md Faruque Ahmad et al., "Nutraceutical Market and Its Regulation," American Journal of Food Technology, 2011, https://doi.org/10.3923/ajft.2011.342.347.

7 Debjit Bhowmik, Harish Gopinath, B. Pragati Kumar, S. Duraivel, "Nutraceutical-A Bright Scope and Opportunity of Indian Health Market."

8 Palthur, Palthur, and Chitta, "Nutraceuticals: A Conceptual Definition." 
It is also important to regulate nutraceuticals without unduly compromising consumer rights to take greater responsibility for their own good health.

\section{REGULATION ON NUTRACEUTICAL PRODUCTS IN MALAYSIA}

The Ministry of Health Malaysia is vested with the authority to regulate and implement relevant laws on the regulation of food and pharmaceutical products in Malaysia. When it comes to classifying whether a product belongs to the food or drug category, two departments under the Ministry came into the spotlight, as stated in Table 1, namely: National Pharmaceutical Regulatory Agency (NPRA) and Food Safety \& Quality Division (FSQD). ${ }^{9}$

Table 1: Guide to Classification of Food-Drug Interface Products

\begin{tabular}{|c|c|c|}
\hline \multicolumn{3}{|c|}{ Product/Ingredients } \\
\hline $\begin{array}{l}\text { Pure form of } \\
\text { active ingredient } \\
\text { (singly or in } \\
\text { combination) }\end{array}$ & $\begin{array}{l}\text { Natural products that } \\
\text { are not traditionally } \\
\text { used as food and of } \\
\text { medicinal value }\end{array}$ & Food base \\
\hline $\begin{array}{l}\text { - Vitamin } \\
\text { - Mineral } \\
\text { - Amino acid } \\
\text { - Fatty acid } \\
\text { - Fibre } \\
\text { - Lyophilized } \\
\text { - Bacteria } \\
\text { - Enzyme }\end{array}$ & $\begin{array}{l}\text { - Alfalfa } \\
\text { - Spirulina } \\
\text { - Royal jelly } \\
\text { - Noni juice } \\
\text { - Pegaga tablet } \\
\text { - Herbal product } \\
\text { - Rooibose tea } \\
\text { - Tongkat ali (powder } \\
\text { or sachet) } \\
\text { - Manja harum }\end{array}$ & $\begin{array}{l}\text { - Less than } 80 \% \text { food } \\
\text { ingredients or more than } \\
20 \% \text { active ingredients of } \\
\text { natural products with } \\
\text { pharmacological/theraputic } \\
\text { properties, singly or in } \\
\text { combination. But if the } \\
\text { latter possess high } \\
\text { potencies, the product shall } \\
\text { be reviewed by the } \\
\text { Committee, even if they } \\
\text { contain less than } 20 \% \text { of } \\
\text { these ingredients } \\
\text { - } 80 \% \text { or more food } \\
\text { ingredients (singly or in } \\
\text { combination) }\end{array}$ \\
\hline
\end{tabular}

9 Focus group discussion between authors and officers of NPRA held on $10^{\text {th }}$ October 2017. 


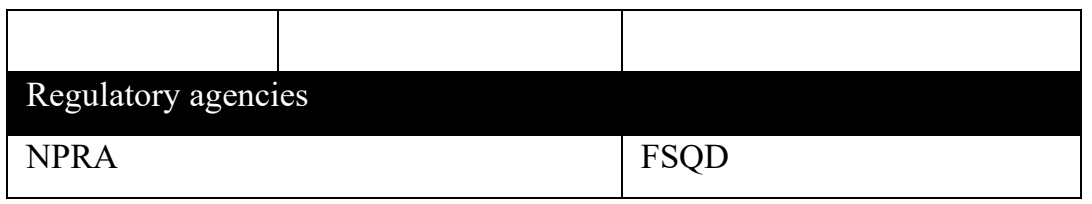

Source: National Pharmaceutical Control Bureau, Ministry of Health, Malaysia. ${ }^{10}$

\section{National Pharmaceutical Regulatory Agency (NPRA)}

NPRA is responsible for regulating nutraceutical products that fall under the category of drugs. Regulation 7 of the Control of Drugs and Cosmetics Regulation 1984 expressly "prohibits manufacture, sell, support, import, possess or administer of any product unless the product is a registered product and that person holds the appropriate licence required and issued by the Drug Control Authority (DCA)". The DCA is an executive body established under the Control of Drugs and Cosmetics Regulations 1984 entrusted to ensure the safety, quality, and efficacy of pharmaceuticals, health, and personal care products that are marketed in Malaysia. In its Term of Reference, the DCA is given the authority to: -

- "review matters related to product registration;

- consider recommendations proposed by the secretariat and register any product subject to such conditions as it may impose, reject any application for the registration of any product, grant exemptions, issue such certification required by any country importing such a product, suspend or cancel registration of any product, make decisions related to regulatory policies;

- maintain a register of the products registered; and

- impose requirements for registration of products". ${ }^{11}$

10 The data in the table is the summary of a compilation by the food-drug interphase committee https://www.npra.gov.my/images/Announcement/2015/NRC-2015day2/TMHS04-P-SuSiewChing03-08-2013.pdf.

11 Drug Control Authority, "Terms of Reference," Ministry of Health Malaysia, 
Safety and quality of a product under the category of drug is assured by strict registration procedures, supervision, and enforcement. The enactment of such mandatory procedures is meant to minimise the risks of having defective drugs on the market. At the same time, it accords protection towards consumers from fraudulent or misleading product information so long as the product is classified as drugs. It is to be noted that the DCA does not have jurisdiction to deal with food products, but is mainly in charge of drugs. Neither does it have jurisdiction over products that are classified as 'in between food or drugs'. In relation to nutraceuticals, they are not directly or automatically categorised as pharmaceutical drugs and do not fall under the purview of the DCA. As some nutraceuticals may fall in between the two, the Ministry of Health Malaysia has published the Guide to Classification of FoodDrug Interface Products to act as a classification scheme effective from $9^{\text {th }}$ July 2014 (herein 'The Guideline') as a guideline for product classification. $^{12}$

On the other hand, if the product in question is found to contain "less than $80 \%$ of food-based ingredients and more than $20 \%$ of the active ingredients", it will be classified as a drug. NPRA would be the authority responsible for drug registration, monitoring, and enforcement. Despite the above methods of classification, there may exist some other products with specific ingredients, such as those containing high potencies yet with less than $20 \%$ of active ingredients. In this regard, these products will be reviewed by a panel of committees appointed by the Ministry of Health Malaysia which has the authority to decide its classification. The same practice is also observed in the event of uncertainties on the issue of efficacy and safety of these products. Manufacturers of pharmaceutical drugs need to adhere to registration procedures that embrace safety requirements imposed by the DCA, as well as compliance with Good Manufacturing Practice (GMP). The DCA is responsible to perform clinical tests or require manufacturers to conduct tests at certified laboratories. Public safety

https://www.npra.gov.my/images/Images/pdf/dca/DCA_Term_Of_Ref_ modified_170113.pdf.

12 National Pharmaceutical Regulatory Agency, "Guide to Classification of Food-Drug Interface Products," National Pharmaceutical Regulatory Agency, 2015 , https://www.npra.gov.my/images/Announcement/2015/NRC-2015day2/TMHS04-P-SuSiewChing03-08-2013.pdf. 
issues are always the paramount concern and the government via the DCA and the NPRA are monitoring the matters seriously in ensuring safe consumption of nutraceuticals.

\section{Food Safety \& Quality Division (FSQD)}

Under the Guideline, a product is classified as food if it contains " $80 \%$ or more of food ingredients, either single or in combination, and with equal to or less than $20 \%$ of biologically active ingredients of natural products with pharmacological and/or therapeutic properties". ${ }^{13}$ All food products are directly regulated and monitored by FSQD under the auspices of the Food Act 1983. Section 17 of the Food Act 1983 and Regulation 18 of the Food Regulations 1985 require food products to be safe for consumption and prohibit the acts of false labelling and deceiving advertisement.

The absence of a specific definition for nutraceuticals in Malaysia (as mentioned above) leads to the issue of categorisation of products that cannot be automated. Since there are two separate agencies empowered to control and regulate nutraceutical products in Malaysia, it gives rise to different standards and procedures applicable to industry players. As the NPRA and the FSQD specify their own standard procedures to be adhered to, it opens up possibilities of the same product to be treated differently depending on which agency is governing it.

Based on the focus group discussion held with the FSQD, several noteworthy issues were discovered particularly in relation to the regulation of nutraceuticals. ${ }^{14}$ In terms of function, the FSQD is responsible for the planning, implementation, monitoring, and evaluation of the Food Safety and Quality Programme that is implemented at national, state and district levels, entry points, and local authorities. The main objective is to protect the public against health hazards and fraud in the preparation, sale and consumption of food and facilitating trade. The FSQD receives mandate as food regulator from the Food Act 1983 and its regulations.

13 National Pharmaceutical Regulatory Division, Ministry of Health Malaysia, Drug Registration Guidance Document (DRGD), (2016) revised (2019): 53-62.

14 Focus group discussion between authors and officers of FSQD held on $11^{\text {th }}$ April 2017. 
Officers from the FSQD were of the view that the Food Act 1983 is a piece of legislation that regulates food manufacturing industries on a self-regulation basis. Their view and observation are based on their experience in handling cases related to food safety. Their main responsibility is to ensure that the safety of food remains with manufacturers. The FSQD does not hold any responsibility to ensure food safety in any part of the food manufacturing processes. The guidelines and regulations contained in the Food Act 1983 and its regulation are applicable to food manufacturers whereby they are responsible to ensure all stages of the production and distribution of food satisfies the prescribed legal requirements - in particular, health protection, protection against fraud, and hygienic handling of food. Food manufacturers must examine and make available for examination the food/goods according to the good manufacturing procedures. The Food Act 1983 and its regulations provide a long list of guidelines for food manufacturers to ensure safety and quality compliance.

The Food Act 1983 is a self-regulatory legal instrument that the industry should be familiarised with. However, the FSQD claimed that awareness about the existence of the Food Act 1983 amongst manufacturers is still very much desired ${ }^{15}$. As a result, food manufacturers were found to be neglectful of the quality and safety requirements in the Food Act 1983 and its regulations. The FSQD has been putting effort into educating the industry by organising seminars or hands-on training to increase the level of awareness amongst industry members. Also, due to the non-compulsory nature of these training, the low level of participation from industry members is alarming. ${ }^{16}$ The FSQD was also vested with regulatory authority to police the Food Act 1983 and Food Regulations. Since food is not a category that is treated as exclusively as drugs, the enforcement mechanism remains a crucial problem for the department due to small manpower and limited resources.

15 Focus group discussion between authors and officers of FSQD held on $11^{\text {th }}$ April 2017.

16 Neither data nor statistic was provided by the FSQD, but this general information was revealed during the focus group discussion. 


\section{Efficacy and safety issues}

In Malaysia, it is a common practice by local manufacturers of nutraceutical products to register and label them as food supplements. Obviously, registration requirements for food supplements are not as stringent as those imposed on pharmaceutical products and hence, this explains why many nutraceuticals are registered under the former rather than the latter categories. Consequently, it is not a legal obligation to comply with the above-mentioned safety requirement hence skipping the strict monitoring procedures applicable to drugs. It is not a requirement to perform clinical testing or lab test to ensure the safety, efficacy, and credibility of the product. Food supplements can be made available for purchase freely in the open market.

On the other hand, once the nutraceutical products are classified as pharmaceutical drugs, they may only be sold to consumers over the counter at registered pharmacies and some may also require prescriptions before they could pass hand to consumers. As far as food products are concerned, they are regarded as non-registrable products because they are presumed to be safe based on the fact that it is possible to extrapolate from a known history of exposure to them. In contrast to drugs, they have no such widespread exposure history, and hence it is not possible to maintain such a presumption. In short, food products can reach the market without any registration requirements since evaluation is not necessary before it is marketed. This means that the safety standard of the said product is ambiguous and can only be inspected upon complaints received from consumers.

\section{Misleading health claims and advertisements}

Section 16 of the Food Act 1983 prohibits the acts of false labelling which includes "false, misleading or deceptive as regards its character, nature, value, substance, quality, composition, merit or safety, strength, purity, weight, origin, age or proportion" that contravenes the purpose or objectives of Food Act 1983. On the other hand, Section 17 of the Food Act 1983 clearly forbids false or misleading health claims on advertisements. To supplement these two provisions, Regulation 18(6) of the Food Regulations further provides that one is not allowed to make any claims that are not justifiable or substantiated. 
Other kinds of prohibitions mentioned in Regulation 18(6) includes:

- "claims stating that any particular food will provide an adequate source of all essential nutrient;

- claims implying that a balanced diet or a combination of a variety of foods cannot supply adequate amounts of all nutrients;

- claims suggesting that food can prevent, alleviate, treat or cure a disease, disorder or other physiological function;

- claims that cause the consumer to doubt the safety of similar food; and claims that arouse or exploit fear in the consumer."

Nevertheless, there is a lack of evidence to suggest that the FSQD has been able to effectively monitor the manufacturer's compliance with the above regulations. In one case involving a nutraceutical-millionaire company, D'Herbs were found guilty under Section 17 of the Foods Act 1983 for promoting misleading advertisements of his two nutraceutical products. ${ }^{17}$ The company also confessed that nutraceutical products sold which "could improve blood circulation" and "improve immunisation system" were not true and was not substantiated with any clinical evidence. Hence, it infers that all promises made in the advertisements were false hope to consumers which may be detrimental to their health after consuming the products for a long period of time. ${ }^{18}$ However, the same advertisement was also published on their website and such health claims were not removed, hence exposing online consumers to further safety risks.

On the other hand, manufacturers of nutraceuticals in Malaysia (including some ASEAN countries) have relied heavily on testimony-

17 Bernama, "D'Herbs company fined RM11,000 for misleading advertisements," The Sun 2017, https://www.thesundaily.my/archive/2170152-HTARCH429147.

18 Mahyuddin Daud et al., "'Unsafe' Nutraceuticals Products on the Internet: The Need for Stricter Regulation in Malaysia," in The 5th International Conference on Information Technology for Cyber and IT Service Management 2017 (Indonesia: IEEExplorer, 2017); BERNAMA, "Iklan Bertentangan Akta Makanan, Syarikat D'Herbs Didenda RM11,000,' Astro Awani, 2017, http://www.astroawani.com/berita-malaysia/iklanbertentangan-akta-makanan-syarikat-dherbs-didenda-rm11-000-133179. 
based marketing strategy with a lack of credible scientific evidence. ${ }^{19}$ Generally, the evidence on the efficacy of local nutraceuticals are limited and scanty and prompts safety issues and the adverse impact of the consumption of those products. Due to the booming of social media, nutraceutical manufacturers have taken such opportunities to market their products online with heavy reliance on unsubstantiated testimonies. This research also discovered that some manufacturers even went as far as making therapeutic health claims that are dubious and remain unsubstantiated, such as healing cancer, heart problems, high blood pressures, and the likes. ${ }^{20}$ Although consumers can lodge a report to the Malaysian Communications and Multimedia Commission (MCMC) for publishing false information online under the purview of Section 211 and 233 of the Communications and Multimedia Act 1998, the action of taking down of misleading online advertisements may serve as temporary measures to stop its dissemination. Some may not even take down misleading online advertisement if there are no complaints received on the matter.

Based on the above analysis, it was found that the present legal framework regulating nutraceuticals requires improvement to address the above issues. The authors now turn to examine the legal framework applicable in Japan to learn the best practices and useful experiences that may be adopted in Malaysia.

\section{REGULATION OF NUTRACEUTICALS IN JAPAN}

The proliferation of consumption of nutraceuticals has prompted regulatory efforts at the global stage due to increased awareness of their potential health and safety risks towards consumers. In its own terms, Japan refers to nutraceuticals as a health food, which is systematically regulated. Before analysis of the categories of health food in Japan is made, it is significant to understand briefly that all consumer-related laws and regulations are supervised by the Consumer Affairs Agency

19 Helmi Haja Mydin, "The Dangers of 'Natural' Remedies," New Straits Times, 2015, https://www.nst.com.my/news/2015/09/dangers-'natural' remedies.

20 Daud et al., "'Unsafe' Nutraceuticals Products on the Internet: The Need for Stricter Regulation in Malaysia." 
(CAA) established on $1^{\text {st }}$ September $2009 .{ }^{21}$ The CAA is an independent government agency that reports directly to the Prime Minister of Japan. The CAA acts as the central agency and regulator that leads and becomes the driving force on consumer-related administrative services, which includes regulatory and monitoring roles similar to the FSQD under the Ministry of Health Malaysia. The CAA grants approval to products that intend to bear specific health claims after adhering to necessary requirements to ensure efficacy and market regulation. On the other hand, the Ministry of Health, Labour, and Welfare regulates medicines where strict regulations are in place, similar to the DCA. There are three types of functional foods that are authorised to bear function claim:

1. Foods for Specified Health Uses (FOSHU);

2. Foods with Nutrient Function Claims (FNFC) and;

3. Foods with Function Claims. ${ }^{22}$

The system or scheme, which started in 1991, is specifically known as Foods for Specified Health Use (FOSHU), under the authority of the CAA. FOSHU symbolises;

"food containing ingredients with functions for health and officially approved to claim its physiological effects on the human body. It is intended to be consumed for the maintenance or promotion of health or special health uses by people who wish to control health conditions, including blood pressure or blood cholesterol". ${ }^{23}$

Before any FOSHU product can be legally allowed to enter the market, the CAA is mandated to perform rigorous assessment via the submission of experimental data and other documents to ensure that the product is equally effective and safe for consumption. This means that

21 Consumer Affairs Agency Japan, "Towards a Safe and Prosperous Life with Consumers' Peace of Mind,” 2018, https://www.caa.go.jp/en/about_us/booklet/pdf/00booklet_en.pdf.

22 Consumer Affairs Agency Japan, 22.

23 Ministry of Health Labour and Welfare Japan, "Food for Specified Health Uses (FOSHU)," Ministry of Health Labour and Welfare Japan, 2019, https://www.mhlw.go.jp/english/topics/foodsafety/fhc/02.html. 
any health claim made by the manufacturer or producer of the product must obtain approval from the CAA. ${ }^{24}$ The paramount consideration is to ensure that consumers are able to make wise decisions and be well informed before they decide to purchase a FOSHU product. However, such approval is not obligatory if manufacturers do not wish to label their products as FOSHU.

In terms of laws and regulations, FOSHU products are heavily regulated in the sense that rigorous assessment and evaluation of the safety and effectiveness of proposed specified health uses is a mandatory requirement as imposed by the government. The specific requirements for FOSHU approval as imposed by the CAA are;

i. Effectiveness on the human body is clearly proven;

ii. Absence of any safety issues (animal toxicity tests, confirmation of effects in the cases of excess intake, etc.);

iii. Use of nutritionally appropriate ingredients (e.g. no excessive use of salt, etc.);

iv. Guarantee of compatibility with product specifications by the time of consumption;

v. Established quality control methods, such as specifications of products and ingredients, processes, and methods of analysis.

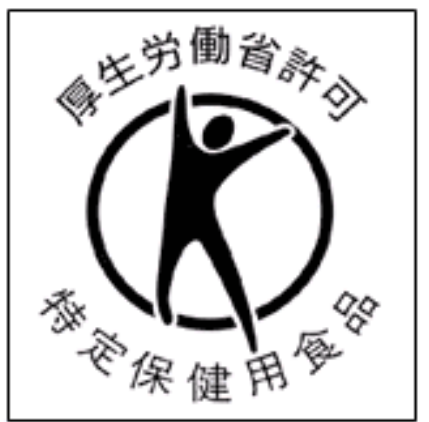

Figure 1: Seal for FOSHU Approval

Source: The Ministry of Health, Labour and Welfare, Japan

24 Focus group discussion between authors and Dr. Tsuyoshi Chiba, Head of Department of Food Function and Labelling, National Institute of Health and Nutrition Japan on 5th December 2018. 
As far as FOSHU categories are concerned, for the purpose of FOSHU approval, other than the 'regular' FOSHU, there are three categories, namely; qualified FOSHU, standardised FOSHU, and reduction of disease risk FOSHU. Qualified FOSHU embraces "food with a health function which is not substantiated on scientific evidence that meets the level of FOSHU, or the food with certain effectiveness but without an established mechanism of the effective element for the function".

Meanwhile, standardized FOSHU is meant for, "foods with sufficient FOSHU approvals and accumulation of scientific evidence", while reduction of disease risk FOSHU, "is permitted when the reduction of disease risk is clinically and nutritionally established in an ingredient". ${ }^{25}$ The processes for obtaining FOSHU approval is summarised in the following chart:

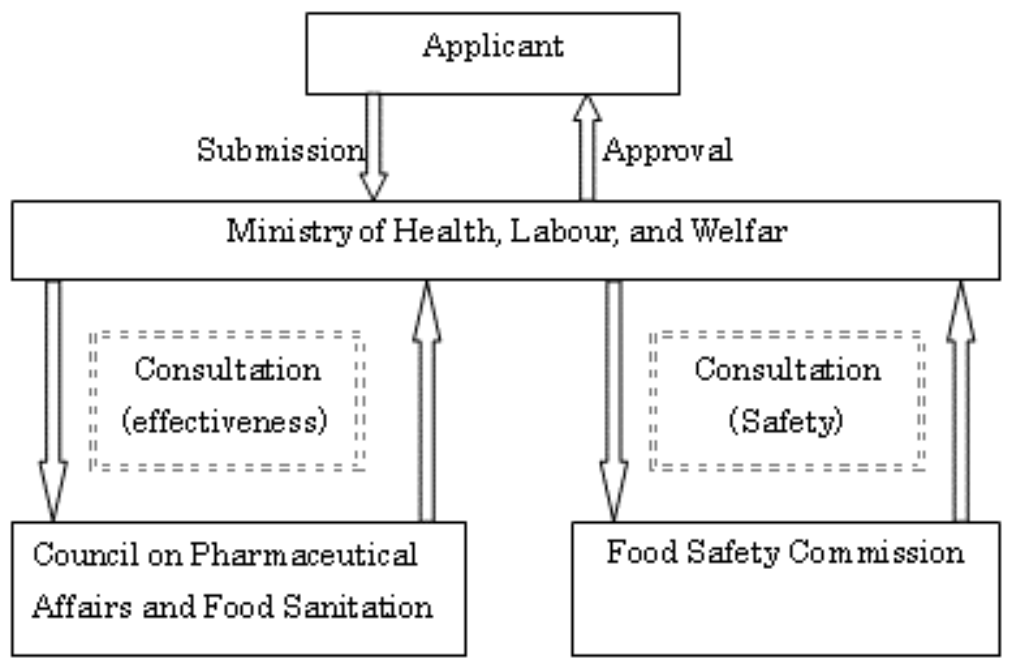

Figure 2: Flow Chart of FOSHU Approval

Source: The Ministry of Health, Labour and Welfare, Japan. ${ }^{26}$

One of the significant features of the FOSHU system is that it requires the manufacturers to ensure clear and correct labelling to prevent any

25 Ministry of Health Labour and Welfare Japan, "Food for Specified Health Uses (FOSHU)."

26 https://www.mhlw.go.jp/english/topics/foodsafety/fhc/02.html 
misleading information to the consumers. Therefore, before FOSHU approval can be granted, the manufacturer must;

"tabulate both published available publications and internal reports on the effectiveness of the product and/or its ingredients and provide a summary of each available publication or report. The tabulation must include in vitro metabolic and biochemical studies, in vivo studies, and randomized controlled trials on Japanese people". ${ }^{27}$

It is quite interesting to note that despite the rigorous clinical process that FOSHU products have to go through, manufacturers managed to sell them for as cheap as 140 yen per product and still make a profit. FOSHU products can easily be found in local stores, in the form of daily food products such as green tea.

The second category of health food in Japan is Foods with Nutrient Function Claims (FNFC). It is used to:

\begin{abstract}
"complement "the daily requirement of nutrients (vitamins, minerals, etc.) which tend to be insufficient in everyday diet. Given that the food product contains certain amounts of nutrients whose function has already been substantiated by scientific evidence, it can bear a nutrient function claim prescribed by the Standards without submitting a notification to the government". ${ }^{28}$
\end{abstract}

It is worth noting that there was a regulatory shift in the health food system when the government decided to introduce 'Foods with Function Claims' (FFC) in 2015. ${ }^{29}$ The FFC aims to permit manufacturers to make claims for the function based on their own evidence embracing both safety, and effectiveness. This means that instead of clinical trials which is a requirement under FOSHU, the new the FFC allows systematic literature reviews as scientific evidence to prove the claim of the related health benefits. Product liability remains

27 Kazuhiko Yamada et al., "Health Claim Evidence Requirements in Japan,"The Journal of Nutrition 138, no. 6 (2008), https://academic.oup.com/jn/article/138/6/1192S/4670290.

28 Consumer Affairs Agency Japan, "Towards a Safe and Prosperous Life with Consumers' Peace of Mind."

29 Consumer Affairs Agency Japan. 
with the business owner or manufacturer - a similar position to the FSQD in Malaysia. Manufacturers who wish to have the FFC labels on their products may submit information relating to food safety, effectiveness and relevant information on adverse health effects to the Secretary-General of the CCA - based on scientific evidence. However, unlike FOSHU, the CCA shall not evaluate the safety and effectiveness of the said product. Products bearing the FFC labels are allowed to claim specified functions that can be achieved, such as "helpful for maintaining and promoting health", "helps maintain good GI condition" or "slows fat absorption". It is to be noted that food products that are labelled as a nutritional supplement, health supplement, or nutrient controlling food are considered as 'foods in general' and hence are not allowed to label any function claim. The FFC is also seen as an alternative to FOSHU - a lesser level for classification of food with health claims, in case the product does not qualify in a stricter FOSHU group. ${ }^{30}$ The role of the National Institute of Health and Nutrition Japan is to provide information on the safety and efficacy of health foods to consumers. Consumers may lodge complaints directly to the CAA for any issues over healthy foods.

\section{ENHANCING CURRENT REGULATION - LESSON FROM THE JAPANESE FOSHU SYSTEM}

It is observed that the strength of the functional food systems in Japan lies in the mandatory requirement of scientific clinical trials or evidence. Essentially, the FOSHU system gives paramount importance to the maintenance of health via the prevention of lifestyle-related diseases based on the consumption of nutraceuticals supported with scientific evidence. ${ }^{31}$ Based on the preceding discussion, it is observed that there is a need to enhance the current legal mechanism to regulate nutraceuticals in Malaysia. Some of the challenges which have been identified include the absence of a specific definition for the term nutraceuticals, which leads to another problem of the absence of

30 Focus group discussion between authors and Dr. Tsuyoshi Chiba, Head of Department of Food Function and Labelling, National Institute of Health and Nutrition Japan on 5th December 2018.

31 Ishi Khosla, "Diet Diary: Functional Foods and Japanese FOSHU Foods For Specified Health Us," The Indian Express, 2018, https://indianexpress.com/article/lifestyle/health/diet-diary-functionalfoods-and-japanese-foshu-5154423/. 
standalone classification for nutraceuticals or food supplements. It is therefore proposed that Malaysia should adopt a new classification for categories of nutraceutical or alternatively to introduce the concept of functional foods with three specific categories under FOSHU (Foods for Specified Health Uses, Foods with Nutrient Function Claims and Foods with Function Claims). These functional foods should be placed under the authority of FSQD, so that food products which fit into these three categories can be better regulated.

Another issue relates to irresponsible marketing strategies involving unsubstantiated testimonials and misleading claims due to a lack of, or inadequate research and controlled clinical trials. ${ }^{32}$ With the increasing number of nutraceutical products in the local market, consumers are posed with increasing risk of harm if their safety, quality and efficacy remain unchecked or unregulated. Indeed, intense and reliable research is inevitable to ascertain whether existing nutraceutical products in the market are really safe and efficient as inappropriate use of these products would put the consumers' health at risk and eventually leads to adverse impacts. Health claims on foods should always be substantiated scientifically. As the current regulatory system suffers from a lack of quality control to regulate nutraceutical products which fall under the category of food or food supplements, in comparison to the strict procedures imposed on pharmaceutical drugs, it is proposed that nutraceuticals undergo more rigorous safety evaluation. Thus, it is inappropriate to classify them as food, but as a standalone category, similar to the FOSHU classification in Japan. There is also a need for nutraceutical products to undergo clinical or lab tests before they can be marketed to ensure that efficient clinical data of its health and medical benefits are obtained to enable consumers to make a well-informed decision before consuming the products.

Despite strict and heavy regulation, pharmaceutical drugs may still be found harmful to consumers. It is therefore not surprising that such harmful effects are produced by the food supplements that are not required to undergo various tests and procedures. For instance, the NPRA has been receiving reports of cases involving adverse reactions to alternative medicines from time to time. This includes the "contamination or substitution with herbs known to be toxic (such as Magnolia, Aristolochia, Chapparal), contamination with heavy metals

32 Daud et al., "'Unsafe' Nutraceuticals Products on the Internet: The Need for Stricter Regulation in Malaysia." 
as well as the illegal inclusion of a drug (for example, corticosteroids, analgesics, hypoglycemic agents)" 33 . Emulating a systematic FOSHU scheme in particular, where the requirement of clinical evidence of efficacy or expert evidence would be an avenue to overcome the problem of unsubstantiated testimonials and misleading claims. Undeniably, it would be time-consuming and would implicate additional cost on the part of nutraceutical manufacturers but consumers' safety remains as a primary concern.

\section{CONCLUSION}

Enhancing the current legal framework and mechanism is inevitable through imposing rigorous safety requirements and strict adherence to acceptable standards of safety and quality on nutraceutical products. Adopting some important features of the FOSHU system which has been successfully practiced in Japan would be necessary to close the gap in current regulation on nutraceuticals in Malaysia. After all, the ultimate aim of moving towards a stricter regulation scheme is mainly to prevent unwanted adverse impacts on consumers as well as to facilitate the sustenance of human health with greater certainty, substantiated with scientific evidence.

The FOSHU system in Japan may be considered as a model where nutraceutical products that bear the FOSHU mark have gone through preclinical tests and are therefore evidenced-based. One of the significant features of the FOSHU system is that it requires the manufacturers to ensure clear and correct labelling to prevent any misleading information to consumers. Therefore, before FOSHU approval can be granted, the manufacturer must "tabulate both published available publications and internal reports on the effectiveness of the product and/or its ingredients and provide a summary of each available publication or report. The tabulation must include in vitro metabolic and biochemical studies, in vivo studies, and randomized controlled trials on Japanese people.

33 National Pharmaceutical Regulatory Agency, "Senarai Produk Dikesan Mengandungi Bahan Terlarang Yang Diterima Melalui Pelaporan Kesan Sampingan Ubat," National Pharmaceutical Regulatory Agency, 2017, http://npra.moh.gov.my/index.php/recent-updates/adulterated-productsunregistered. 
Other than FOSHU products, another category is known as 'Foods with Function Claims' (FFC). The FFC aims to permit manufacturers to make claims for the function based on their own evidence embracing both safety and effectiveness. This means that instead of clinical trials which is a requirement under the FOSHU system, the new FFC allows systematic literature reviews as scientific evidence to prove the claim of the related health benefits. Product liability remains with the business owner or manufacturer - a similar position to the FSQD in Malaysia. Manufacturers who wish to have the FFC labels on their products may submit information relating to food safety, effectiveness and relevant information on adverse health effects.

Essentially, the strength of the functional food system in Japan lies in the mandatory requirement of scientific clinical trials or evidence, a feature of which should be emulated by Malaysia to improve the existing legislation. In a nutshell, it is proposed to strengthen the existing regulatory structure and process by enforcing stringent safety criteria and strict adherence to the appropriate protection and quality standards on nutraceutical products. To close the gap in current nutraceuticals regulation in Malaysia, it would be appropriate to adopt some important features of the FOSHU system which has been successfully practised in Japan. In spite of everything, the ultimate objective of moving towards a heavier regulatory scheme is primarily to avoid harmful adverse effects and to promote the protection of human health with greater confidence, based on scientific proof. 